\title{
SALES POLICIES AND PRICE DISCRIMINA- TION UNDER THE CLAYTON ACT
}

\author{
BRECK P. MCALLISTER"
}

NoT so many years ago goods were sold after price higgling in the market and the final result depended on the relative trading skill and cupidity of both buyer and seller. In such an economy uniformity of price and quality of goods were unknown. With the growth of industry and nationwide retail as well as wholesale distributing facilities this simple process has been displaced by what may be conveniently described as the one-price policy in which the seller publicly announces his sales policy and the price at which his goods will be sold. This is now practically the rule in American industry. But it is a rule with many exceptions. The exceptions are the price cutters, and it may be safely assumed that they exist in every industry. They have many of the characteristics of the old selling and marketing methods. They ply their trade by making special prices to customers by any one of a variety of methods. The process is cumulative and if one starts others follow and soon a price structure, built up by years of hard work, represented by published price lists, and established business policies, is reduced in practice to chaos and confusion and as a result there is not even a decent profit for any one.

Conditions such as these are necessarily accentuated in times of depression when overproduction meets with diminishing demand and inventories are liquidated, in many cases from compelling reasons, regardless of cost. It is then that competing sellers struggle to secure their share, or more, of the going business, and conditions turn from bad to worse.

The purpose of this inquiry is to consider whether the law offers any help or hindrance in the attainment of at least rensonable stability of price. The one-price policy must be accepted as a sound business policy, but certain complicating factors in modern marketing have raised questions as to the incidence of the law on traditional marketing policies as they are adapted to these conditions. Then too, there are questions raised by the efforts of a given industry, organized as a trade association, to induce its members to adhere to their publicly announced prices and policies.

* A. B. University of California, 1923, LL.B. Harvard, 1926, Ph.D. Brookings Graduate School, 1929; author of Lord Hale and Businoss Affcolcd with a Public Interest (1930) 43 HARv. L. REv. 759; member of Now York Bar. 
This leads to a consideration of Section 2 of the Clayton Act. That section provides that "it shall be unlawful for any person engaged in [interstate] commerce to discriminate in price between different purchasers ... where the effect of such discrimination may be to substantially lessen competition or tend to create a monopoly in any line of [interstate] commerce: Provided, That nothing herein contained shall prevent discrimination in price between purchasers of commodities on account of differences in the grade, quality, or quantity of the commodity sold, or that makes only due allowance for difference in the cost of selling or transportation, or discrimination in price in the same or different communities made in good faith to meet competition: And provided furthe;, That nothing herein contained shall prevent persons engaged in selling goods, wares, or merchandise in [interstate] commerce from selecting their own customers in bona fide transactions and not in restraint of trade." I

Section 2 of the Clayton Act was designed primarily to outlaw the practices of large corporations of local price-cutting for the purpose of destroying a local competitor. The report of the Judiciary Committee of the House is explicit on this point. The report goes on to say that:

"We are not dealing with an imaginary evil or against ancient practices long since abandoned, but are attempting to deal with a real, existing, widespread, unfair and unjust trade practice." =

It is of interest to note that since the passage of the Clayton Act in 1914, there has been a dearth of instances in which Section 2 has been used to deal with this practice. ${ }^{3}$ Whether the reason for this is to be found in the deterrent effect of the existence of the statute, or in the development of more tolerant competitive methods, does not concern us. The fact of present significance is that, in the contest for mastery between the one-price system and higgling in the market, Section 2 is being used as a weapon on the side of the one-price system.

Beginning about 1919, the Federal Trade Commission inaugurated the practice of sponsoring Trade Practice Conferences at which representatives of a given industry met in conference

138 Stat. 730 (1914), 15 U. S. C. $\$ 13$ (1926).

2 Report of House Cominitiee on the Judiciary, 63d Cong., 2d. Sezs., Misc. H. R. Rep., v. 2, no. 627, Miay 6, 1914, at 8.

3 Porto Rican American Tobacco Co. v. American Tobacco Co., $30 \mathrm{~F}$. (2d) 234 (C. C. A. 2d, 1929), certiorari denied, 279 U. S. 858, 49 Sup. Ct. 353 (1929), is the outstanding instance. See also Federal Trade Commission v. Galena Signal Oil Co., 2 F. T. C. 446 (1920), and Federal Trade Commission v. Fleischmann Co., 1 F. T. C. 119 (1918). 
and under the aegis of the Commission, and subject to its approval, drew up and agreed to be bound by a set of rules designed to eliminate unfair methods of competition in the in-

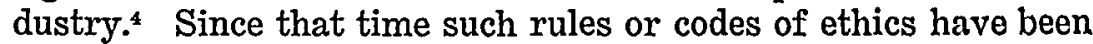
drawn up by about one hundred industries, ${ }^{\circ}$ ranging in size and importance from the petroleum industry at the top of the scale to, with all due deference, the baby carriage industry at the bottom of the scale. In about seventy-five of these codes there is a rule declaring, in one form or another, that price discrimination is an unfair method of competition. In many instances the rule is stated in the exact language of Section 2 of the Clayton Act with the added clause that such discrimination is an "unfair method of competition." " As such, the rule is merely an injunction to obey the law and is to be interpreted according to available court decisions.

The statute prohibits price discrimination where the effect may be to substantially lessen competition or tend to create a monopoly "in any line of commerce," but it was not until 1929, in the case of George Van Camp \& Sons Company v. American Can Company, ${ }^{8}$ that it was authoritatively declared by the Supreme Court that the statute meant just what it said. The Circuit Court of Appeals for the Second Circuit had held in the earlier cases of Mennen Company v. Federal Trade Commission $^{9}$ and National Biscuit Company v. Federal Trade Commis$\operatorname{sion}^{10}$ that the statute only applied to such discrimination as might substantially lessen competition or tend to create a monopoly in the line of commerce in which the discriminator was engaged. The court attempted to ascertain the intent of Congress by reference to reports of congressional committees and other. extraneous aids to statutory construction and concluded that

${ }^{4}$ On June 5, 1926, the Federal Trade Commission issued an ordor creating a Division of Trade Practice Conferences to meet the growing demand of industries for conferences. This order is reported in 2 FEDERAL TRADE Regulation SERvice (1930-1932) par. 2501, published by Commerco Clearing House, Inc.

5 The rules approved by the Federal Trade Commission are reported in 2 Federal Trade Regulation Service (1930-1932) 3355 ct $s c q$.

6 No useful purpose would be served by a complete catalogue of the industries that have adopted a price discrimination rule and of the many and various forms that this rule takes. The curious reader will find tho rules collected and indexed in Federal Trade Regulation Servico, supre note 5.

IA typical example is Rule 4 of the rules for the Plumbing \& Henting Industry, approved September 23, 1929, and revised October 16, 1031, as reported in 2 Federal Trade REGULATION SeRvice (1930-1932) par. 2568.

8278 U. S. 245, 49 Sup. Ct. 112 (1929).

○ 288 Fed. 774 (C. C. A. $2 d, 1923$ ), certiorari denied, 262 U. S. 759, 43 Sup. Ct. 705 (1923).

10299 Fed. 733 (C. C. A. 2d, 1924), certiorari denied, 266 U. S. 613, 4 b Sup. Ct. 95 (1924). 
they pointed to this result.11 The Supreme Court, however, found that the words "in any line of commerce" were clear and unambiguous. As the court said, "There is nothing to construe." ${ }^{2}$ The Supreme Court rejected the reports of congressional committees and other aids to statutory construction on the ground that such extraneous aids could only be used in cases of ambiguity, and it found none.

The decision in the Von Camp case has given new life to Section 2 of the Clayton Act. The merchandising policies and practices of a producer engaged in interstate commerce must now be considered not only from the point of view of their effect on competitors of the producer but also from the point of view of their effect on retailers and wholesalers and others in the broad competitive field in which his goods move.

But the litigation of the $\operatorname{Van} C a m p$ case was merely a preliminary skirmish in the effort of certain packing companies to recover treble damages from the American Can Company based on an alleged price discrimination. ${ }^{13}$ That case removed the obstacle presented by the Mennen and National Biscuit cases and soon after that decision the first suit, in which the Ladoga Can-

\footnotetext{
11 Judge Rogers quoted from the Report of THe JUdiciary CoMarirtee of THE HOUSE OF REPRESENTATIVES, supra note 2, to the effect that the evil aimed at was the practice of large corporations of local price cutting to destroy a local competitor. However, this report was rendered on May 6, 1914, 51 Cong. Rec. 8201, and at that time Section 2 did not contain the phrase "in any line of commerce." The bill before the House prohibited price discrimination "with the purpose or intent to thereby destroy or wrongfully injure the business of a compctitor of cither such purchascr or seller." (italies ours.) Judge Rogers did not quote the full text of the House Report. He omitted the following sentence: "This section expressly forbids discrimination in price... when such discrimination is made with the purpose or intent to thereby destroy or wrongfully injure the business of a competitor either of such dealer or seller." Supra note 2 . The elimination of this phraseology would seem to disqualify the House Report as an aid to determining intent of Congress in adopting the substitute phrase "in any line of commerce." Further, the phrase finally adopted is consistent with the discarded phrase and, if anything, is broader in scope. The argument outlined above is fully developed in the reply brief of appellant, George Van Camp \& Sons Company, in the Van Camp case, supra note 8.
}

In Henderson, The Federal Trade Commission (1924) at 276, the author suggests that the original phraseology "of a competitor of either such purchaser or seller" was ungrammatical because there was no antecedent to the word "such." He adds that the change may have been made to make the statute grammatical and he finds no reason to suppose that there was any intention to limit its scope.

12 Supra note 8, at 253, 49 Sup. Ct. at 113.

13 Section 4 of the Clayton Act, 38 STAT. 731 (1914), 15 U. S. C. $\$ 15$ (1926), provides that "any person who shall be injured in his business or property by reason of anything forbidden in the antitrust laws" may sue therefor and shall recover threefold the damages sustained by him and the cost of suit, including a reasonable attorney's fee. 
ning Company was plaintiff, came to trial. The result was a verdict for plaintiff in the amount of $\$ 30,000$. Judgment was entered for $\$ 105,000$, being treble the amount of the verdict together with plaintiff's reasonable attorneys' fees in the amount of $\$ 15,000$. Both sides appealed from the judgment to the Circuit Court of Appeals, but we are concerned only with defendant's assignments of error. ${ }^{14}$ The evidence showed that defendant American Can Company was the largest manufacturer in the United States of tin cans used as containers by packer's of canned goods and that plaintiff Ladoga Canning Company was a relatively small concern engaged in canning food stuffs and selling its products in competition with hundreds of other canners. One of the largest competitors of plaintiff was the Van Camp Packing Company. Plaintiff charged that American Can Company discriminated in price in favor of Van Camp; that this favorable price for cans gave Van Camp a great competitive advantage over plaintiff; that the effect of this discrimination was to substantially lessen competition in the line of commerce in which plaintiff and Van Camp were engaged and tended to create a monopoly in Van Camp in certain lines of commerce; and that plaintiff had suffered damage. American Can Company admitted that it made a more favorable price to Van Camp than to plaintiff. It attempted to bring the discrimination within the provisos of Section 2 on the ground that Van Camp purchased in greater volume than plaintiff, that unless given the special price Van Camp would go into the can business and that the price was made to meet a price made by a competitor of American Can. The court held that there was ample evidence to justify the jury in finding that the allowances and rebates granted to Van Camp and denied to plaintiff and other's amounted to as much as eighteen per cent of the price paid by Van Camp and that this special price was a material factor in the sale of the finished product. It was proved that the cost of a tin can amounted to nearly one-third of the entire cost of $n$ can of food and in some instances equalled or exceeded the cost of the food. The court also held that since Ladoga had made a prima facie case of discrimination the burden of proof was on American Can Company to establish its justification and that the jury was justified in rejecting the evidence offered by American Can on this issue. It appeared that American Can advertised widely that all its cans of like character and size were sold at the same price to all customers and that all prices were f. o. b. Indianapolis. On a certain day, however, American Can made two contracts with Van Camp, one binding and the other not, the one not binding naming the published price made to all

\footnotetext{
${ }_{14}$ Ladoga Can Co. v. American Can Co., 44 F. (2d) 763 (C. C. A. 7th, 1930), certiorari denied, 282 U. S. 899, 51 Sup. Ct. 183 (1931).
} 
of Van Camp's competitors and the one binding containing the agreements for special allowances and rebates. The latter was guarded with the utmost secrecy.

In disposing of American Can Company's contention that the discrimination was based on Van Camp's volume of purchases and that therefore, as a matter of law, the evidence should not have been submitted to the jury, the court used this significant language:

"That defendant's price discrimination was due to its desire to retain Van Camp's business may be conceded. Such an object was perfectly justifiable, but under the statute it could not be attained through price discriminations save as the volume of the latter's business justified it, or unless the discounts were granted to meet competition. Setting to one side the last named justification for the discrimination, as we must, in view of the jury's rejection of it, defendant's course, if approved, must find support solely in the volume of Van Camp's business. But if the volume of Van Camp's business was the basis of reduced prices, should not such prices have been available to all customers who bought cans of like amount? Were not all canners entitled to know the amount of purchases necessary to obtain the saving in cost of cans? Without such information Van Camp's competitors were not in the same position to plan for future business, and it was this concealment of fact coupled with defendant's assurance that no price reductions were made because of the size or volume of business that cast discredit on defendant's after-theact protestation that the discriminations were made because of volume of business." 15

The court held that the evidence of American Can's public statements that all customers were treated alike, coupled with the secrecy surrounding the special deal with Van Camp, justified the jury in finding that the discrimination was not based on quantity. It would seem clear, however, that a manufacturer who would avoid a charge of price discrimination and the weighing of his conduct by a jury, cannot safely make a special price to a favored customer, even though in good faith based on quantity, unless he offers the same opportunity to all other customers. So in this case if American Can had announced that customers who purchased over a million cans a year would be entitled to receive a certain discount and then had granted an additional discount to some favored purchaser in that class, there would be a discrimination and Ladoga would have a cause of action even though the volume of its purchases would never qualify it for the quantity discount. In other words, Ladoga would not have to show, in such a case, that it was discrimi-

15 Ibid. 767 . 
- nated against. It would be enough to show that there was a discrimination within the meaning of the statute which had injured its business.

Of course, Ladoga would have to satisfy the other requirements of the statute and, among other things, show that the favored customer gained a definite competitive advantage and that the effect might be to substantially lessen competition, and so on, and prove its damages. In the principal case, Ladogn offered evidence to show that for five years prior to the making of the special price the business of Van Camp remained almost at a standstill and five years afterwards had increased 300 por cent. This rate of increase was found to be much greater than that of the canned goods business of the country during the same period. The court held that from this evidence the jury might have properly found that the effect of the price discrimination was to substantially lessen competition or tend to create a monopoly in the line of commerce in which Ladoga and Van Camp were engaged. It is important to note that American Can made the discriminatory price on tin cans and as far as Van Camp was concerned this was simply one item in the cost of production of a can of food. We have seen, however, that it was a substantial item and in some instances equalled the cost of the food that went into the cans. If, contrary to the fact, it had appeared that the cost of a can was an insignificant item in the cost of the finished product, the court might well have held, as a matter of law, that the effect of the discrimination could not give the recipient of the favored price such a competitive advantage as would tend to "substantially" lessen competition in that line of commerce. Therefore, such evidence could not properly go to the jury. In the present case the cost of cans was approximately one-third of the cost of the finished product. As to what point must be reached below that figure to justify the court in holding as above is of course a question of degree to be answered by the exercise of judgment.

It remains to consider the question of damages. American Can insisted that Ladoga's evidence failed to show that it had suffered any damage and if any damage was shown it was so speculative, remote, uncertain and unascertainable as to afford no basis for a determination by a court or jury. The court rejected both contentions. It appeared that immediately following the execution of the favorable contract, and because of it, Van Camp commenced price cutting. As a result Ladoga, which for five years previously had been operating at a profit, was compelled to operate at a loss. In order to negative the suggestion that Ladoga's losses were due to its own inefficiency or carelessness, Ladoga was permitted to show that other canners similarly situated also operated at a loss during the same period. The 
court said :

"The case is one for the application of the rule which denies defendant's right to take refuge behind the alleged uncertainty or indefiniteness of the plaintiff's proof of damages which was occasioned by defendant's own wrongdoing and its concealment of such fact from the injured party." 1s

Ladoga showed the usual rate of profit under normal operations and the profit which various canners were able to make prior to Van Camp's price cutting. This, supplemented by proof that Van Camp's price cutting was made possible by the discriminatory price and proof of Ladoga's losses, afforded a sufficient basis for an inference as to the effect of the price cutting on plaintiff's business.

Any uncertainty that might exist as to the validity of this rule of damages has been removed by the Supreme Court in the recent case of Story Parchment Company v. The Pattcrson Parchment Paper Company, ${ }^{1 \pi}$ involving a suit for treble damages based on an alleged conspiracy to destroy plaintiff's business in violation of the Sherman Act. It is now clear that the courts will not hold a plaintiff to strict proof of his damages in cases of this sort. If plaintiff can show a causal connection between the wrong and the damage, that is, if plaintiff can show what the Supreme Court described as "the fact of damage," then plaintiff will be required only to do the best he can under the circumstances to show the extent of the damage. He will not be denied relief if his proof is based on circumstantial evidence and depends on inferences.

To return to our original question, this decision illustrates clearly the type of proof necessary to show a violation of Section 2. It is evident that sporadic and trivial discriminations can scarcely produce that substantial lessening of competition which is necessary to show a violation of law. It is also evident that large corporations, more than small ones, will have to take to heart the lesson learned by the American Can Company because a departure from its published prices by a large corporation is fraught with a greater possibility of producing the effect on competition condemned by the statute than a similar departure

\footnotetext{
${ }^{16}$ Ibid. 769 .
}

17282 U. S. 555, 51 Sup. Ct. 248 (1931). The Supreme Court reversed the Circuit Court of Appeals for the First Circuit. 37 F. (2d) 537 (C. C. A. 1st, 1930); see Comment (1930) 39 YALE L. J. 1085. While the facts in this case and the Ladoga case are somewhat different, the statements of the law in the opinions of the circuit courts in these two cases represent conflicting points of view. The fact that the opinion of the Supreme Court in the Story Parchment Co. case is in harmony with the opinion in the Ladoga case lends added significance to the denial of certiorari by the Supreme Court in the latter case. 
by: a small corporation. The extent to which this decision will vitalize Section 2 remains to be seen. Its importance should not be over-emphasized because this section is technical, and is so hedged around with provisos and traps to catch an over-zenlous plaintiff that it is not to be supposed that the Ladoga case will at once open a new and inviting field for litigation.

II

Nevertheless, it cannot be doubted that both the Van Camp and Ladoga cases have sharpened the teeth of Section 2 and increased the importance to producers of adopting merchandizing policies which will not be susceptible to the charge of discrimination. In general there are two policies that are commonly followed. One is to classify the trade into jobbers, wholesalers and retailers, or some similar functional classification, and to allow to wholesalers or jobbers a greater discount, or lower price, than is allowed to retailers. The other is to base prices on the quantity purchased, the greater the quantity the grenter the discount. ${ }^{18}$ Under this policy no classification of customers is made. Quantity, and quantity alone, determines the price. An attempt will be made to consider some of the questions that are raised by the two sales policies outlined above. The Monnen and National Biscuit cases illustrate these sales policies and in spite of the fact that their authority has been substantially impaired by the decision in the Van Camp case, they must nevertheless be reckoned with. They also illustrate the practical business situations that raise the legal questions.

The functional classification would involve no difficulties in a market in which all possible customers could be readily pigeonholed as jobbers, wholesalers or retailers, but in many industries such is not the fact, or, in some cases, considered the fact. The rapid growth of chain stores, department stores, mail order houses and cooperative buying pools has disturbed this traditional hierarchy. We are not concerned with the questions of business policy that are involved in the efforts of the manufacturer to please all classes of customers, but we are concerned with the questions that must be answered if legal complications are to be avoided.

The sales policy of the Mennen Company in effect in 1921 involved a classification of its trade into wholesalers and retailers and the allowance to wholesalers of a greater discount than that allowed to retailers. Pursuant to this plan the company refused to recognize as wholesalers a group of retailers

\footnotetext{
18 These and other sales policies are discussed in COPELAND, Principles of Merchandising (1924) c. xi.; Converse, Manketing Methods AND Policies (1921) c. xxii.
} 
who had organized on a cooperative basis for the purpose of pooling their purchases and securing the wholesaler's' discount. In adopting this sales policy the company aligned itself on the side of the so-called "legitimate" distributors as against the growing chain stores, department stores, mail order houses and cooperative buying pools. ${ }^{10}$ The Federal Trade Commission attacked this sales policy as an unfair method of competition in violation of Section 5 of the Federal Trade Commission Act, $=0$ and as a price discrimination in violation of Section 2 of the Clayton Act. It found that in many instances a retailer would purchase as large a quantity as a wholesaler; that as a result the Mennen Company was in the position of making a different price to purchasers of a like quantity; and that this difference was not justified by any difference in the cost of selling or any other difference permitted by the provisos. It also found that the effect of this discrimination might be to substantially lessen competition, not between the Mennen Company and its competitors, but between the distributors. The Commission issued a sweeping order requiring the Mennen Company to cease and desist "from discriminating in net selling prices, by any method or device, between purchasers of the same grade, quality and quantity of commodities, upon the basis of a classification of its customers as 'jobbers', 'wholesalers', or 'retailers', or' any similar classification which relates to the customer's' form of organization, business policy, business methods, or to the business of the customers' membership or shareholders." $=1$

It is impossible to escape the conclusion that by the issuance

19 The Federal Trade Commission found that at least fifty-three concerns, many of them corporations, cooperative or mutual in form and functioning as distributors at wholesale, were classified as retailers by the Mennen Co. See Federal Trade Commission v. The Mennen Co., 4 F. T. C. 258 (1922), Findings of Fact, paragraphs 4 (c) and (d) at 277. It was also found that the growth of these concerns had been very rapid and that the aggregate gross sales of twelve such corporations in 1920 were $\$ 22,890,282.31$ and that the sales so made were to the retail trade at wholesale prices. Ibid. par. $11(\mathrm{f})$ and $(\mathrm{g})$ at 281 . The commission also found that there was no evidence to show that it cost the company more to sell the independent retailers than the chain stores. Ibid. par. 17 (b) at 282.

2038 STAT. 719 (1914), 15 U. S. C. \$ 45 (1926). The court, applying the test laid down in Federal Trade Commission v. Gratz, 253 U. S. 421, 40 Sup. Ct. 572 (1920), concluded that the sales policy of the Mennen Company was not an unfair method of competition. The court said: "So far as appears, they undertook, acting independently, to sell their lawfully acquired property in the ordinary course, without deception, misrepresentation, or oppression, and at fair prices, to purchasers villing to take it upon terms openly announced." Supra note 9, at 777.

21 See Federal Trade Commission v. The Jiennen Co., supra note 19, at 283. An identical order was issued by the Commission on a similar set of facts in Federal Trade Commission v. South Bend Bait Co., 4 F. T. C. 355 (1922). 
of this order the Commission was attempting to revolutionize the sales policies of American business. Had this order been sustained the so-called trade discount based on a functional classification of purchasers as wholesalers, jobbers, retailers, etc., would have had to be abandoned and sales policies would have had to be framed within the four corners of the provisos of Section 2. A manufacturer could make a different price to different purchasers only if based on differences in the "grade, quality or quantity" sold or in the "cost of selling or transportation" or if "made in good faith to meet competition." In short, the manufacturer would be driven to the use of the quantity discount. Such a result is indeed a far cry from the original purpose of Section 2.

The Mennen Company petitioned the Circuit Court of Appeals to review the order and secured a reversal of the Commission. The opinion of the court discloses a failure to analyze and state clearly the questions presented in their relation to the facts. The net result is a confusion of language which gives little comfort to the puzzled lawyer. The holding of the court, however, is that the sales policy in question was not an unfair method of competition, and did not involve discrimination and, even if discriminatory, there was no showing that the discrimination had substantially lessened competition between the Mennen Company and its competitors, and without such a showing there could be no violation of Section 2 .

In holding that this sales policy did not involve a discrimination the court said:

"What the Mennen Company has done, was to allow to 'wholesalers' who purchased a fixed quantity of their products a certain rate of discounts while to the 'retailers' who purchased the same quantities it denied the discount rates allowed to the 'wholesalers'. This does not indicate any purpose on the part of the Mennen Company to create or maintain a monopoly. The Company is engaged in an entirely private business and it has a right freely to exercise its own independent discretion as to whether it will sell to 'wholesalers' only or whether it will sell to both 'wholesalers' and 'retailers', and if it decides to sell to both it has a right to determine whether or not it will sell to the 'retailers' on the same terms it sells to the 'wholesalers'. It may announce in advance the circumstances, that is, the terms, under which it will sell or refuse to sell." ${ }^{22}$

$$
\because \quad *
$$

"In accordance with these opinions we have no doubt that the Mennen Company had the right to refuse to sell to retailers at all, and if it chose to sell to them that it had the right to

\footnotetext{
22 Supra note 9, at 779 .
} 
fix the price at which it would sell to them, and that it was under no obligation to sell to them at the same price it sold to the wholesalers. It did not discriminate as between retailers but sold to all retailers on one and the same scale of prices. And it did not discriminate as between wholesaler's but sold to all wholesalers on one and the same scale of prices. There is nothing unfair in declining to sell to retailers on the same scale of prices that it sold to wholesalers even though the retailers bought or sought to buy the same quantity the wholesalers bought." $=3$

The court seems to have leaned heavily on the right of a manufacturer to select his own customers. This is expressly recognized in the last proviso of Section 2.24 But this proviso,

23 Supra note 9 , at 781 .

24 "And provided further, That nothing herein contained shall prevent persons engaged in selling goods, wares, or merchandise in commerce from selecting their own customers in bona fide transactions and not in restraint of trade." 38 STAT. 730 (1914), 15 U. S. C. $\$ 13$ (1926).

The operation of this proviso is well illustrated in Great Atlantic \& Pacific Tea Co. v. Cream of Wheat Co., 227 Fed. 46 (C. C. A. 2d, 1915). The Cream of Wheat Co. had a sales policy of selling only to wholesalers at a fixed discount. It refused to sell to anyone else. The chain store was anxious to secure Cream of Wheat products at the wholesalers' discount in order to sell at retail at cut prices. On the refusal of the Cream of Wheat Co. to continue to sell to it it brought suit alleging that this was a discrimination. The court after observing that "this suit is really brought to force defendant to continue to sell to this single retailer" [p. 48] went on to say: "We have not yet reached the stage where the selection of a trader's customers is made for him by the Government." Ibid. 49.

In Cudahy Packing Co. v. Frey \& Son, Inc., 261 Fed. 65 (C. C. A. 4th, 1919) (see also Federal Trade Commission v. Cudahy Packing Co., 1 F. T. C. 199 (1918)) the question was presented as to whether or not the refusal to sell to a jobber because he would not maintain resale prices was a discrimination. The Circuit Court of Appeals held that the resale price maintenance plan of the Packing Co. was legal and that the refusal to sell to the price-cutting jobber was simply an exercise of the right to select customers. The authority of the decision on the latter point is shaken by the reversal by the Supreme Court of the holding as to the legality of the resale price maintenance plan, Frey \& Son, Inc. v. Cudahy Packing Co., 256 U. S. 208, 41 Sup. Ct. 451 (1921). Assuming the legality of the plan, a manufacturer would seem to be within his rights in refusing to sell because the customer is a price-cutter. This proposition is not altogether free from doubt, howerer, because the right to select customers is qualified by the words "in bona fide transactions and not in restraint of trade." While these qualifying words have not as yet been applied in any case, they would seem to justify a holding that the systematic and rigorous exercise of the right of selection by refusing to sell to pricecutters is competent evidence, along with other evidence, of an unlawiul plan to maintain resale prices. This proviso was involved in the recent case of Sidney-Morris \& Co. v. National Association of Stationers, $40 \mathrm{~F}$. (2d) 620 (C. C. A. 7th, 1930). The circuit court reversed the district court which had sustained a demurrer to plaintiff's complaint. The complaint charged a particular manufacturer with having discriminated in 
while it would clearly justify a holding that a person might discriminate in any way he sees fit, or for any reason that appeals to him, in the selection of customers, would scarcely extend to a case in which there was a discrimination in price among the customers selected. To say that a person may select, is simply to say that a person who is not selected has no cause to complain and that the government will not compel his selection. But it is a very different thing to say, as the court said, that because of this right to select, a person who has been selected cannot be heard to complain of discrimination because he need not have been selected. The Commission contended that there had been discrimination among the customers selected, and at no point in its opinion does the court squarely meet the proposition that a like quantity of goods was sold to different purchasers at different prices. The court simply ignored it.

The court in the Mennen case avoided consideration of the effect of the sales policy in the line of commerce in which the wholesalers and retailers were engaged, but since the decision in the $\operatorname{Van}$ Camp case this inquiry will have to be mado by courts in cases in which a discrimination is found. The question would then be, whether or not the refusal of the Mennen Company to grant the wholesalers' discounts to the cooperative buying pool was a discrimination that would have the effect of substantially lessening competition "in any line of commerce." It appeared that the Mennen Company had not discriminated between its so-called "legitimate" wholesalers or between its retailers. It may be assumed that wholesalers and retailers are each engaged in a separate "line of commerce" and therefqre that there is no competition between them to be affected.

By such an approach the legality of the trade discount might be sustained without denying the obvious discrimination between buyers of the same quantity. But this, on a shifting market, may lend scant comfort to the sales manager who, anxious to avoid legal complications, is confronted with the following dilemma. To grant the wholesalers' discount, or some other special discount not granted to ordinary retailers, to the chain stores, department stores or cooperative buying pools is to discriminate against the small independent retailer. To refuse the wholesalers' discount is to discriminate between purchasers of a like

price against plaintiff in violation of Section 2 of the Clayton Act in refusing to sell to him because he would not maintain alleged fixed resalo prices, and joined as defendants a large number of other manufucturers and certain wholesalers and retailers on the ground that they had foinod in the conspiracy to cut off plaintiff's supply. The court held that the action was not one based on a conspiracy but that the defendants who had joined in the refusal to sell plaintiff made themselves liable for the damages suffered by plaintiff growing out of the alleged violation of Section 2 . Clearly the complaint charged more than a mere selection of customors. 
quantity, that is, between the wholesalers and the chain stores, department stores and cooperative buying pools.

The sales manager must deal with the realities of his business. His dilemma represents the conflict of interest between the small independent retailer, on the one hand, and the chain stores, department stores, mail order houses and cooperative buying pools on the other hand. If he grants the wholesalers' discount to the latter class he undermines the competitive strength of the independent retailer. If he denies it, he preserves the balance of competitive strength in the retail field by taking from the chain stores, and other large purchasers, an advantage that they demand by reason of their size and, as we have noted, puts himself in the position of selling to them at a higher price than to wholesalers even though they purchase the same or a greater quantity than the wholesalers.

The sales policy questioned in the case of National Biscuit Company v. Federal Trade Commission 25 was based on a straight quantity discount. Unlike the policy of the Mennen Company, the National Biscuit Company favored the chain stores, department stores and mail order houses as against the fast disappearing present channels of distribution. In order to remove the competitive advantage enjoyed by chain stores under this policy, a group of independent retailers pooled their orders and demanded a discount based on their combined purchasing power. The National Biscuit Company refused to grant their request and presumably this decision was dictated by a desire not to offend the powerful chain stores. The Federal Trade Commission found that this sales policy was discriminatory and tended to substantially lessen competition and create a monopoly in the retail distribution of the company's products, and issued an appropriate order to correct the disadvantage.:s

The Circuit Court of Appeals reversed the Commission and, as in the Mennen case, held that there was no discrimination and even if there was, Section 2 was violated only if the discrimination substantially lessened competition between the $\mathrm{Na}$ tional Biscuit Company and its competitors. On this latter point the court found that this sales policy would have no such effect. The court said, on the contrary, that the refusal of the National Biscuit Company to grant the discounts to the buying pool

${ }^{25}$ Supra note 10. The proceedings before the Federal Trade Commission are reported in 7 F. T. C. 206 (1924). See also the companion case of Federal Trade Commission v. Loose-Wiles Biscuit Co., 7 F. T. C. 218 (1924).

26 The order to cease and desist required the company either (1) to base chain store discounts on the quantity delivered to each branch of the chain, treating each store as a separate purchaser, or (2) to allow separate and individual purchasers or owners of stores to pool their parchases for the purpose of computing discounts, 7 F. T. C. 206, 217. 
would presumably tend to drive the dissatisfied customers to its competitors.

The opinion of the court that there was no discrimination seems indefensible. A strict adherence to its publicly announced sales policy would require the National Biscuit Company to grant the quantity discount to any customer who qualified by the quantity purchased, whether he was a wholesaler, retailer, chain store, mail order house or cooperative buying pool. When the company undertook to differentiate between chain stores and the independent retailers' cooperative buying pool, it was departing from its announced policy and was looking at the character of the purchaser in determining the discount. The court ignored this and made the inexplicable statement that:

"Equal opportunity is given to all. ... The determining factor - is the quantity consumed; there is no discrimination among purchasers. All are supplied on equal terms according to the quantity purchased." $2 \pi$

Future courts, on a similar state of facts, will have to follow the Van Camp case and consider whether the discrimination has the effect of substantially lessening competition in the channels of distribution. The Federal Trade Commission in the instant case found that it did. ${ }^{28}$ It found that the chain stores gained a substantial competitive advantage over the independent retailers. . This finding, if supported by evidence, is binding on the courts. ${ }^{20}$ The National Biscuit Company might argue that it was confronted with a dilemma, because to refuse the discount to the cooperative buying pool would result in a discrimination between chain stores and independent retrilers, whereas to grant the discount would result in a discrimination between the retailers composing the pool and those on the outside. This situation further emphasizes the practical impossibility of adopting any sales policy that will be wholly free from some discrimination. As far as the Clayton Act is concerned, however, the complete answer of the National Biscuit Company

${ }^{27}$ Supra note 10, at 739.

28 The Commission found that independent retailers were at a competitive disadvantage with chain stores and that in general the offect of the refusal of the company to grant the quantity discount to cooporativo buying pools was to tend to substantially lessen competition in the retail distribution of the company's products. See Federal Trade Commission v. National Biscuit Co., 7 F. T. C. 206, Findings of Fact, paragraphs 22, 23, 24 and 26, at 215-216. The Commission also found that it cost no moro to sell to a specified number of independent retailers than it did to soll the same number of stores of a chain system. Ibid. par. 17, at 214.

${ }^{29}$ Federal Trade Commission v. Curtis Publishing Co., 260 U. S. 568, -43 Sup. Ct. 210 (1923) ; International Shoe Co. v. Federal Trado Commission, infra note 33. 
would be to adhere rigidly to a quantity discount which is expressly permitted under Section 2, irrespective of the effect on competition. A sales policy based on a straight quantity discount is undoubtedly the safest one for a sales manager who would avoid any complications under the Clayton Act.

It should be noted that of all the various discriminations expressly permitted by the provisos, the quantity discount is the only one of practical value in the preparation of a sales policy. To say that you may discriminate because of differences in the "grade" or "quality" of the commodity is simply to say that you may charge more for something that costs more to produce. The same may be said as to "cost of transportation." The proviso that differences in the "cost of selling" will justify discrimination is troublesome in its practical application and may be difficult of proof. $^{30}$ Further, the discrimination in these last two instances must make "only due allowance" for these differences. These hardly furnish a secure foundation for a sales policy.

The implications of this conclusion are far reaching. In adopting a policy of a straight quantity discount the producer definitely favors those of his customers who purchase in large quantities, namely, chain stores, department stores, mail order houses and cooperative buying pools. The independent retailer who must meet this competition if he is to survive is placed at a distinct competitive disadvantage. Further, under this policy the ultimate consumer in the rural districts and small towns must pay more for his goods than the city dweller. This, of course, is due to the fact that ordinarily the retailer or wholesaler in the big city will purchase in greater quantity than in the small town. This last condition does not exist under a policy involving the functional classification of customers because under that policy all wholesalers are sold at one price irrespective of the quantity purchased.

There is a further complication in the question of transportation charges. ${ }^{31}$ In many industries it is customary for a manufacturer to sell his products f. 0 . b. factory and let the buyer pay the freight bill. In other industries the country is divided into zones and a delivered price is fixed for each zone. Under both of these policies different prices are made based on differ-

${ }^{30}$ The difficulties in establishing this justification are illustrated in the failure of the Miennen Co. and the National Biscuit Co. to prove to the satisfaction of the Federal Trade Commission that it cost more to sell to independent retailers than to the units of a chain store system. See notes 19 and 28, supra. Even if it is successfully established that there is a difference in the cost of selling, by what standard is it to be determined whether the difference in price makes "only due allowance" for that difference?

31 See Copeland and Converse, supra note 18. 
ences in the cost of transportation, and this is expressly permitted in the proviso to Section 2. But in some industries it is customary to make a uniform price to all buyers regardless of their location. Under this policy the manufacturer necessarily fixes some figure that represents an average cost of transportation and reflects it in his selling price. But suppose a buyer located near the factory complains that this policy is discriminntory in that in effect he is helping to pay the freight bill of the more distant buyers and claims that because of his location he is entitled to a lower price. His contention raises a question of merchandising policy that must be considered in its bearing on the legal question of discrimination.

Many other considerations enter into the decision as to whether in a given situation the one policy or the other is to be adopted and it is not the purpose of this discussion to review the economic merits and demerits of each policy. However, since the decision in the Van Camp case any given sales policy, except the quantity discount, which is expressly permitted irrespective of its effect on competition, is subject to judicial inquiry to determine whether or not it substantially lessens competition in the competitive field of the wholesalers, retailers, chain stores, department stores, mail order houses and the like. Neither the business man nor the lawyer can guess on which side of the scale any court will cast the weight of its decision. If producers are driven to the sanctuary of the quantity discount in order to escape this judicial control, then Section 2 of the Clnyton Act is indeed a meddlesome bit of legislation operating in a manner never intended by Congress and to an end unsought by that body.

As long as Section 2 is on the statute books these questions may have to be decided, and it remains to consider whether there is any escape from the difficulties discussed above.

The policy of the statute was expressed by the Supreme Court in the Van Camp case, as follows:

"The fundamental policy of the legislation is that, in respect of persons engaged in the same line of interstate commerce, competition is desirable and that whatever substantially lessens it or tends to create a monopoly in such line of commerce is an evil." 32

A realistic point of view would recognize that some discrimination is inevitable in any sales policy, and, admitting the discrimination, would emphasize the inquiry as to the effect on competition. The court would then consider the dilemma that confronts the sales manager in its bearing on the legal ques-

32 Supra note 8 , at 254, 49 Sup. Ct. at 114. 
tion as to whether or not the effect of the discrimination may be to substantially lessen competition. Confronted with this choice a court might properly ask at the moment whether a classification of chain stores, department stores, mail order houses and cooperative buying pools as wholesalers, if you please, was reasonable, and had due regard for their functions and for the maintenance of a reasonable equality of opportunity in the competitive field. This test of reasonableness does not involve the assumption that all purchasers can be readily pigeonholed as wholesalers or retailers but it does set up a test which will permit the court to take a practical view of the situation. The category of a substantial as against an incidental lessening of competition is a familiar one ${ }^{33}$ and has the advantage of furnishing a flexible standard in future applications of the statute to business policies and factual situations that are apt to be more and more complicated. The probability is that in the growth of the law of price discrimination this category will be more in the forefront of judicial opinions. . $^{34}$

\section{III}

It is difficult to escape the conclusion at this point that Section 2 is a nuisance which may be used by a disgruntled customer

33 Section 3 of the Clayton Act, 38 STAT. 731 (1914), 15 U. S. C. $\$ 14$ (1926), briefly summarized, declares that it shall be unlawful to impose as a condition in connection with the sale of goods, that the purchaser shall not deal in the goods of a competitor of the seller "where the effect of such ... condition ... may be to substantially lessen competition or tend to create a monopoly in any line of commerce." In construing these words the Supreme Court said: "Section 3 condemns sales or agreements where the effect of such sale or contract of sale 'may' be to substantially lessen competition or tend to create monopoly. It thus deals with consequences to follow the making of the restrictive covenant limiting the right of the purchaser to deal in the goods of the seller only. But we do not think that the purpose in using the word 'may' was to prohibit the mere possibility of the consequences described. It was intended to prevent such agreements as would under the circumstances disclosed probably lessen competition or create an actual tendency to monopoly. That it was not intended to reach every remote lessening of competition is shown in the requirement that such lessening must be substantial." Standard Fashion Co. v. Magrane-Houston Co., 258 U. S. 346, 356, 42 Sup. Ct. 360,362 (1922).

To the same effect see International Shoe Co. v. Federal Trade Commission, 280 U. S. 291, 50 Sup. Ct. 89 (1930), involving the same question under Section 7 of the Clayton Act, 38 STAT. 731 (1914), 15 U. S. C. $\S 18$ (1926).

34 The early case of Baran v. Goodyear Tire \& Rubber Co., 256 Fed. 571 (S. D. N. Y. 1919), recognized the importance of this inquiry. In that case a dealer in tires alleged that the Goodyear Company discriminated against dealers by selling tires to automobile manufacturers at a sub- 
to present to a judicial tribunal the substantial conflicts of interest and questions of merchandising policy considered above, to be resolved by the court as best it can by the interpretation of the technical and ill-conceived language of the section. It must also be apparent that the trade associations and the Federal Trade Commission in so far as they are attempting to stamp out price cutting by means of Section 2 have chosen an instrument that is unwieldy and ill-designed for their purpose. The Commission has done nothing to clarify this situation. It has simply approved the inclusion of the rule condemning price discrimination in all its technical aspects in a multitude of codes of ethics without one word of explanation or of caution as to the uses to which it may properly be put. Until the Commission abandons its policy of exercising its jurisdiction by the fiat of its orders, without the explanatory opinion which is such an important part of the judicial process, there is little to be hoped for in the way of light on this confusing situation. ${ }^{35}$ If, by the approval of the price discrimination rule, the Commission intends to align itself on the side of the one-price system, it has chosen an ineffective and misleading way of doing so.

It would seem that under the authority conferred by Section 5 of the Federal Trade Commission Act to prevent unfair methods of competition in interstate commerce a more practical weapon could be fashioned. It is true that the Commission met with rebuffs in the Mennen and National Biscuit Company cases in its effort to declare that the sales policies of those companies were unfair methods of competition. ${ }^{36}$ But in both of those - cases the sales policies were publicly announced and consistently adhered to. The secrecy and deception which were found in the Ladoga case and which ordinarily characterize the price cutter were lacking. The accepted test of an "unfair method of com-

stantially lower price. The court found that there could be no lessening of competition because the two classes of customers were not in competition. To the same effect see S. S. Kresge Co. v. Champion Spark Plug Co., 3 F. (2d) 415 (C. C. A. 6th, 1925), in which it was alleged that tho sale of spark plugs to a manufacturer of automobiles at less than cost, to be compensated by increased prices for replacements, was a violation of Section 2. The court found no lessening of compotition under this policy.

35 In Henderson, The federal Trade Commission (1924) 333-337, the author presents a well considered criticism of the Commission for its failure to present its findings of fact and conclusions in the form of judicial opinions. The futility of the present procedure is well illustrated in Federal Trade Commission v. Wayne Oil Tank \& Pump Co., 1 F. T. C. 259 (1918), in which the complaint charged the respondent with a violation of Section 2 of the Clayton Act and the complaint, findings of fact and order to cease and desist are substantially in the language of Section 2.

${ }^{36}$ See note 20, supra. 
petition", as stated by the Supreme Court in Fedcral Trade Commission v. Gratz, stresses these elements of deception and bad faith. The language of the court is as follows:

"The words 'unfair method of competition' are not defined by the statute, and their exact meaning is in dispute. It is for the courts, not the commission, ultimately to determine as matter of law what they include. They are clearly inapplicable to practices never heretofore regarded as opposed to good morals because characterized by deception, bad faith, fraud or oppression, or as against public policy because of their dangerous tendency unduly to hinder competition or create monopoly. The act was certainly not intended to fetter free and fair competition as commonly understood and practiced by honorable opponents in trade." $3 \pi^{2}$

It is submitted that the available decisions do not preclude the Commission from ruling, if it so desires, that it is an unfair method of competition for a trader to publish a price list, or publicly announce a price, and then make a special price to a favored customer without at the same time offering that special price to all other customers similarly situated. In keeping with the same policy it might also rule that all prices must be publicly announced to the trade, and that it is an unfair method of competition to make any price that is not so announced. Such a rule could have no application to an industry in which, due to the nature of the product sold, this would be impracticable, and, of course, under the rule each trader would remain free to fix his own prices and publish new price lists at any time.

It may be that such a policy could not be made effective without legislation. The history of governmental control of business in this country furnishes one striking example of legislation of the type here discussed. The early federal railroad legislation did not go beyond an attempt to stamp out the abuses connected with rebates and discriminatory rates. The Act to Regulate Commerce of 1887 prohibited rebates and personal discriminations of every sort, and required railroads to publish all rates and fares and to post them conspicuously at all stations, as well as file them with the Interstate Commerce Commission. It also prohibited the charging of any rate or fare unless it was published. ${ }^{38}$ It was not until the passage of the

${ }^{37}$ Supra note 20 at 427,40 Sup. Ct. at 575.

38 Act to Regulate Commerce, 24 STAт. 379 (1887), 49 U. S. C. $\$ 1$ 'et seq. (1926). The Elkins Act, 32 STAT. $\$ 47$ (1903), 49 U. S. C. $\S \S 41-48$ (1926), was designed to strengthen the provisions of the Act of 1887 relating to the observance of published tariffs. For a discussion of the history of this legislation and its relation to rebating and discriminatory rates see RIPLEY, RAIRoADS: RATES AND REgULATION (1912) chapters 
Hepburn Act in 1906, nearly twenty years later, that the Interstate Commerce Commission was given limited power to fix rates. ${ }^{30}$ By this early legislation Congress attempted to impose the one-price policy on the railroads of the country. Necessarily questions of constitutionality would be raised by any similar legislation applicable to business generally. Perhaps the most troublesome question would be whether such legislation could be made applicable to businesses that were not "affected with a public interest.". 40

This whole problem may be regarded as an illustration of a fundamental error into which both courts and Commission are gradually falling. Section 2, mainly designed to prevent the growth of monopoly, has been also turned to the business of preventing unfair practices. As a result, the Commission must defend its orders against price discrimination, no matter how deceitful and unfair, by showing a substantial lessening of competition. Even by shifting to Section 5 of the Federal Trade Commission Act this slippery ground might not be entirely avoided for the courts have shown a disposition to read into the Act the purposes of the anti-trust legislation.11 Experience already begins to indicate that the Commission might operate more effectively if its two functions were kept more distinctly separate, the preservation of the plane of competition from the preservation of competition itself.

xiii, xiv and xv. On this point see New York, New Haven and Hartford R. R. v. Interstate Commerce Commission, 200 U. S. 361, 301, 26 Sup. Ct. 272,276 (1906).

3934 STAT. 589 (1906), 49 U. S. C. $\S 15$ (1926).

40 In the recent case of O'Gorman \& Young, Inc. v. Hartford Fire Insurance Co., 282 U. S. 251, 51 Sup. Ct. 130 (1931), the Supreme Court, by a 5 to 4 decision, upheld a New Jersey Statute prohibiting insuranco companies from allowing a commission to an agent in excess of that allowed to any other agent. The effect of the statute was to prohibit all discrimination in agent's commissions. This statute, like the early rallroad legislation, applied only to a business theretofore found to be "affected with a public interest." The opinion in this case is of interest here as showing the disposition of both the majority and minority of the court to consider the constitutionality of the statute from the point of view of tha relation of the agent's commission to the rate charged the insured, ovor' which the power of the state is clear. The majority found a direct rolntion. The minority found none. This case also illustrates the disposition of the court to regard such legislation as substantially price-fixing legislation. The question of the constitutionality of similar legislation applicabla to business generally is not foreclosed by this decision, and grounds for distinguishing it may be devised, but the attitude of mind of the justices cannot be disposed of so readily.

41 See, e.g., Federal Trade Commission v. Raladam Co., 283 U. S. 643, 51 Sup. Ct. 587 (1931). 